cytosis follows. This is presumably followed in turn by ràpid degradation of cell membranes and associated antigens.

Clearly rapid clearance and phagocytosis of $\mathrm{Rh}$-positive red cells by anti- $D$, anti- $K$, anti-A, or anti-B all lead to definite suppression of the anti-D response. There is also evidence that this suppression is not always complete. Clinically a $R \mathbf{h}$-negative mother may develop anti-D after a first ABO-incompatible $\mathrm{Rh}$-positive pregnancy. In a study in male volunteers five out of $32 \mathrm{Rh}$-negative subjects produced anti-D after a series of injections of ABO-incompatible Rh-positive red cells. ${ }^{9}$ Nevertheless, when a similar series of injections of ABO-compatible $\mathrm{Rh}$-positive cells coated in vitro with anti-D were given none of the recipients developed anti-D. This suggests that anti-D is more suppressive than anti-A or anti-B and raises the possibility that though a predomniant mechanism of immunosuppression is shared by these antibodies anti-D may have a further effect-such as the ability to block any $D$ antigen that escapes the destructive process within macrophages.

\section{PRACTICAL IMPLICATIONS}

Most cases of haemolytic disease of the newborn are due to anti-D, and the current practice of typing mothers and their infants for the $D$ antigen and administering anti-D where there is incompatibility has resulted in an appreciable decrease in the incidence of the disease (B. M. Hibbard, personal communication) and in deaths due to it. ${ }^{10}$ The formation of any other antibodies in these mothers will probably also be largely prevented by the administration of anti-D. Nevertheless, very occasionally a blood group antigen other than $\mathrm{D}$, present in the fetal cells, may escape the destructive process and survive to immunize the mother. There is a hint that this may be so. ${ }^{11}$
In relation to organ transplantation our findings may have relevance to attempts to modify the primary immune response in the recipient to foreign antigens introduced with the graftfor example, on passenger leucocytes. Antibodies directed at any determinant on the donor cells should suppress the immune response to other determinants present.

We are greatly indebted to the blood donors who volunteered for this experiment. The IgG anti-K was prepared by Dr. W. d'A. Maycock and Mr. L. Vallet at the Lister Institute of Preventitive Medicine, and we thank them for their help. We thank Dr. N. C. Hughes-Jones for estimating the concentration of anti- $K$.

This work was supported by the Research Committee of the Mersey Regional Area Health Authority.

Requests for reprints should be sent to Dr. J. C. Woodrow, Department of Medicine, University of Liverpool, Liverpool L69 3BX.

\section{References}

1 Clarke, C. A., et al., British Medical fournal, 1963, 1, 979.

2 Freda, V. J., Gorman, J. G., and Pollack, W., Transfusion, 1964, 4, 26.

3 Combined Study, British Medical fournal, 1966, 2, 907.

4 Freda, V. J., Gorman, J. G., and Pollack, W., Science, 1966, 151, 828

5 Clarke, C. A., et al., Lancet, 1970, 1, 793 .

$6 \mathrm{Uhr}, \mathrm{J}$. W., and Möller, G., Advances in Immunology, 1968, 8, 81.

? Feldman, M., and Diener, E., Fournal of Experimental Medicine, 1970,

131, 247.
${ }^{8}$ Rowley, D. A., and Fitch, F. W., fournal of Experimental Medicine, 1964, 120,987.

9 Stern, K., Goodman, H. S., and Berger, M., fournal of Immunology, 1961,

87, 189.
$10 \mathrm{Hawes}$, W. E., and Mordaunt, V. L., California Medicine, 1973, 118, No. $5,28$.

11 Pollack, W., in Blood Transfusion in Clinical Medicine, ed. P. L. Mollinson, 5th edn., p. 323. Oxford, B!ackwell, 1972.

\title{
Comparison of Intravenous AH 5158 (Ibidomide) and Propranolol in Asthma
}

\author{
C. SKINNER, J. GADDIE, K. N. V. PALMER
}

British Medical fournal, 1975 2, 59-61

\section{Summary}

The cardiac and bronchial effects of AH 5158 and propranolol were compared in a double-blind, placebocontrolled intravenous study on 10 asthmatics. AH 5158, like propranolol, is a non-cardioselective $\beta$-adrenoceptorblocking drug, but unlike propranolol it also has an $\alpha$-adrenoceptor-blocking action. Both drugs produced equivalent cardiac $\left(\beta_{1}\right)$ blockade, but propranolol produced bronchoconstriction, whereas AH 5158 did not. Hence the $\alpha$-blocking action of AH 5158 seems to prevent the bronchoconstrictor effects of propranolol in these patients.

\section{Introduction}

$\beta$-Adrenoceptor antagonists are often used for angina, hyper-

tension, and cardiac arrhythmias. They are not, however, specifically cardioselective, and one of the first introduced, propranolol, may lead to or aggravate bronchoconstriction in asthma. ${ }^{1}$ This risk is less but not absent with cardioselective drugs such as practolol and acebutolol. ${ }^{2-4}$ There is evidence that $\alpha$-adrenoceptors are present in the bronchial muscle and that stimulation of these-for example, by exercise, methoxamine, or histamine-leads to bronchoconstriction. ${ }^{5-7}$ This can be prevented in asthmatics by pretreatment with $\alpha$-receptorblocking drugs such as thymoxamine, phentolamine, phenoxybenzamine, and indoramin. ${ }^{7-8}$

AH 5158 (ibidomide) (5-[1-hydroxy-2-[(1-methyl-3-phenylpropyl $_{2}$ amino] ethyl] salicylamide) is a recently developed drug which, like propranolol, blocks both $\beta_{1}$ - and $\beta_{2}$ - receptors but also has some $\alpha$-receptor-blocking activity. ${ }^{10} 11$ Possibly, therefore, this $\alpha$-blocking action may prevent bronchoconstriction when the drug is given to asthmatics. We have investigated this by comparing the effects of $\mathrm{AH} 5158$ and propranolol in a placebo-controlled trial on asthmatic patients.

\section{Subjects and Methods}

Ten asthmatic outpatients were studied (six men and four women). All gave their consent and understood that their asthma might worsen temporarily. Their mean age was 31.8 (range 18-48) years and their mean weight 65.8 (range 54-79) kg. Eight had extrinsic 
atopic asthma (positive skin test reactions) and two intrinsic asthma (negative reactions). All had blood or sputum eosinophilia or both and all were non-smokers. All had pulmonary function abnormalities typical of bronchial asthma. ${ }^{12}$ They were selected because they had mild airway obstruction and were therefore unlikely to develop a serious worsening of their condition as a result of the experiment. The mean forced expiratory volume in one second $\left(\mathrm{FEV}_{1}\right)$ at the time of study was $81 \%$ of the mean predicted value (range $62-98 \%$ ).

Patients visited the laboratory on three different days, the interval between visits being two to seven days. Each attendance was at the same time to exclude the effect of diurnal variation in ventilatory function. No bronchodilator or other drugs were taken for 12 hours beforehand. At each visit baseline measurements of $\mathrm{FEV}_{1}$ forced vital capacity (FVC), and resting pulse rate were taken. The mean baseline $\mathrm{FEV}_{1}$ varied $220 \mathrm{ml}(8.27 \%)$ and the mean baseline FVC $200 \mathrm{ml}(4.99 \%)$ among the three visits, so that these measurements were comparable at each visit. The FEV ${ }_{1}$ and FVC were recorded in litres (ambient temperature and pressure saturated with water vapour (A.T.P.S.) from the best of three forced expiratory spirograms obtained with a dry wedge spirometer.

After the baseline measurements intravenous AH $515820 \mathrm{mg}$, propranolol $5 \mathrm{mg}$, or placebo (saline) was given double-blind in random order. These doses were used because animal studies had shown $\mathrm{AH} 5158$ to be about four times less potent than propranolol in blocking $\beta$-receptors. ${ }^{13}$ Measurements of $\mathrm{FEV}_{1}, \mathrm{FVC}$, and pulse rate were repeated $5,10,15,30$, and 60 minutes after the injection. Salbutamol (a selective $\beta_{2}$-adrenoceptor stimulant) was then given by aerosol $(200 \mu \mathrm{g})$, and $\mathrm{FEV}_{1}$, FVC, and pulse rate were measured again five minutes later. The patient then performed steady-state exercise on a bicycle ergometer for six minutes, the pulse rate being recorded immediately afterwards. For each patient an exercise work load of 50 to 150 watts had been selected by preliminary study and was maintained on all three days.

\section{Results}

Mean changes in resting pulse rate up to 60 minutes after AH 5158, propranolol, and placebo are shown in table I. Compared with placebo the mean pulse rate after propranolol was significantly decreased at all time intervals $(P<0.05)$, whereas a significant decrease after $\mathrm{AH} 5158$ was seen only at 15 and 60 minutes. A significant difference between propranolol and AH 5158, however, was seen only at 5 minutes. Mean exerciseinduced increases in pulse rate after $\mathrm{AH} 5158$ and propranolol were similar ( 25 and 27 beats/min respectively) and were significantly less than the mean increase after placebo ( 35 beats/min) $(P<0.05)$.

TABLE I-Mean Decreases in Resting Pulse Rate (Beats/min) from Pretreatment Value after AH 5158, Propranolol, and Placebo in 10 Asthmatics

\begin{tabular}{c|c|c|c}
\hline $\begin{array}{c}\text { Minutes after } \\
\text { Injection }\end{array}$ & AH 5158 & Propranolol & Placebo \\
\cline { 2 - 3 } 5 & $3 \cdot 6$ & $9 \cdot 5^{* \dagger}$ & 0.5 \\
10 & $5 \cdot 7$ & $7 \cdot 6^{*}$ & $1 \cdot 6$ \\
15 & $7 \cdot 4^{*}$ & $9 \cdot 7^{*}$ & $1 \cdot 9$ \\
30 & $7 \cdot 2$ & $10.7^{*}$ & 1.6 \\
60 & $11 \cdot 2^{*}$ & $12 \cdot 1^{*}$ & $2 \cdot 5$ \\
\hline
\end{tabular}

${ }^{*} \mathbf{P}<0.05$ for difference from placebo.

The mean changes in $\mathrm{FEV}_{1}$ and FVC are shown in table II. There was no significant change in resting $\mathrm{FEV}_{1}$ at any time after AH 5158 or placebo. Five minutes after propranolol, however, the mean FEV fell by 0.631 , and this was maintained up to 60 minutes. The mean reductions in resting $\mathrm{FEV}_{1}$ with propranolol were highly significant $(P<0.01)$ at all time intervals. In addition the changes in resting FVC after propranolol paralleled those in $\mathrm{FEV}_{1}(\mathrm{P}<0.01)$. Salbutamol produced a mean rise in $\mathrm{FEV}_{1}$ of 0.391 after $\mathrm{AH} 5158,0.481$ after propranolol, and $0.47 \mathrm{l}$ after placebo. There was no statistically significant difference in the response to salbutamol after $\mathrm{AH}$ 5158 , propranolol, or placebo. In the cases of $\mathrm{AH} 5158$ and placebo the mean post-salbutamol $\mathrm{FEV}_{1}$ approached the mean predicted normal value of $3.27 \mathrm{l}$, indicating near maximum bronchodilatation. Similar changes after salbutamol were seen in FVC.

TABLE II-Mean Changes in FEV 1 and FVC after AH 5158, Propranolol, and Placebo in 10 Asthmatics

\begin{tabular}{|c|c|c|c|c|c|c|}
\hline & \multicolumn{3}{|c|}{$\mathrm{FEV}_{1}$ (l) (A.T.P.S.) } & \multicolumn{3}{|c|}{ FVC (1) (A.T.P.S.) } \\
\hline & AH 5158 & Propranolol & Placebo & AH 5158 & Propranolol & Placebo \\
\hline $\begin{array}{l}\text { Predicted normal } \\
\text { Before treatment } \\
\text { After treatment: }\end{array}$ & $\begin{array}{l}3 \cdot 27 \\
2 \cdot 58\end{array}$ & $\begin{array}{l}3 \cdot 27 \\
2 \cdot 76\end{array}$ & $\begin{array}{l}3 \cdot 27 \\
2 \cdot 64\end{array}$ & $\begin{array}{l}3 \cdot 86 \\
4 \cdot 02\end{array}$ & $\begin{array}{l}3 \cdot 86 \\
4 \cdot 03\end{array}$ & $\begin{array}{l}3 \cdot 86 \\
3.99\end{array}$ \\
\hline $\begin{array}{l}5 \mathrm{~min} \\
10 \mathrm{~min} \\
15 \mathrm{~min} \\
30 \mathrm{~min} \\
60 \mathrm{~min} \\
\text { After salbutamol }\end{array}$ & $\begin{array}{l}2.47 \\
2.54 \\
2.56 \\
2.56 \\
2.59 \\
2.98\end{array}$ & $\begin{array}{l}2 \cdot 13^{*} \\
2 \cdot 11^{*} \\
2 \cdot 08^{*} \\
2 \cdot 14^{*} \\
2 \cdot 15^{*} \\
2 \cdot 63\end{array}$ & $\begin{array}{l}2 \cdot 55 \\
2 \cdot 59 \\
2.54 \\
2 \cdot 60 \\
2.58 \\
3.05\end{array}$ & $\begin{array}{l}3.80 \\
3.95 \\
3.94 \\
3.99 \\
3.98 \\
4 \cdot 18\end{array}$ & $\begin{array}{l}3 \cdot 67^{*} \\
3 \cdot 50^{*} \\
3 \cdot 38^{*} \\
3 \cdot 55^{*} \\
3 \cdot 60^{*} \\
3 \cdot 93\end{array}$ & $\begin{array}{l}3.96 \\
3.98 \\
3.90 \\
3.89 \\
3.96 \\
4.18\end{array}$ \\
\hline
\end{tabular}

${ }^{*} \mathrm{P}<0.01$ for differences from $\mathrm{AH} 5158$ and placebo.

\section{Discussion}

Clearly, while intravenous propranolol and $\mathrm{AH} 5158$ in the doses used had equivalent $\beta_{1}$-blocking properties, as shown by the inhibition of exercise-induced tachycardia, propranolol but not AH 5158 produced bronchoconstriction. A difference between the bronchial effects of AH 5158 and propranolol has also been shown in normal people. Thus peak expiratory flow rate during exercise in normal people was reduced by propranolol in doses causing cardiac $\beta$-blockade, ${ }^{14}$ whereas peak flow rate during exercise was unchanged by $\mathrm{AH} 5158$ in cardiac $\beta$-blocking doses. ${ }^{15}$

These findings and our results might suggest that $\mathrm{AH} 5158$ is simply a highly cardioselective $\beta$-adrenoceptor-blocking drug. Evidence in both animals and man, however, indicates that this drug has an unselective $\beta$-adrenoceptor-blocking action similar to that of propranolol. ${ }^{1} 11$ In contrast to propranolol, however, AH 5158 also has pharmacologically significant $\alpha$-receptorblocking properties. Thus studies in man have shown competitive antagonism of the vasoconstrictor effect of locally infused noradrenaline, a response due to $\alpha$-receptor stimulation, after local infusion of $\mathrm{AH} 5158 .^{10}$ Also in man progressive inhibition of the pressor response to phenylephrine after increasing doses of intravenous AH 5158 has been shown, again confirming an $\alpha$-receptor-blocking effect. ${ }^{16}$ This $\alpha$-blocking action is not associated with any antihistaminic properties. ${ }^{17}$ In the present study, reductions in resting pulse rate were slightly less after AH 5158 than propranolol, though the drugs had equivalent cardiac $\beta$-receptor-blocking effects, as shown by a similar degree of inhibition of exercise-induced tachycardia.

We conclude that blockade of the $\alpha$-receptors in the bronchi prevents bronchoconstriction in asthmatic patients which would otherwise develop with the unselective $\beta$-blockade produced by AH 5158. Also, this bronchial protection does not compromise the desired $\beta_{1}$-blocking properties of the drug, so that drugs of this type are likely to be safer than existing adrenoceptor $\beta$-blocking drugs for angina, hypertension, and cardiac arrhythmias in patients with airway obstruction. Moreover, there is evidence that in severe hypertension a combination of an $\alpha$-receptor-blocking drug and a $\beta$-receptor-blocking drug is more effective than a $\beta$-receptor-blocking drug alone. ${ }^{18}$

Our thanks are due to Dr. D. A. Richards, of Allen and Hanburys Research Limited, for supplies of AH 5158, and to Mr. D. McKenzie for technical help.

Requests for reprints should be sent to Dr. K. N. V. Palmer.

\section{References}

${ }^{1}$ McNeill, R. S., Lancet, 1964, 2, 1101

2 Macdonald, A. G., and McNeill, R. S., British fournal of Anaesthesia, $1968,40,508$. 
3 Palmer, K. N. V., et al., Lancet, 1969, 2, 1092

4 Leary, W. P., Coleman, A. J., and Asmal, A. C., South African Medical fournal, 1973, 47, 1245 .

5 Bianco, S., et al., British fournal of Diseases of the Chest, 1972, 66, 27.

6 Snashall, P. D., and Boother, F. A., Bulletin de Physiopathologie Respiratoire, $1972,8,503$.

${ }^{7}$ Bianco, S., et al., British Medical fournal, 1974, 4, 18.

${ }^{8}$ Kerr, J. W., Govindaraj, M., and Patel, K. R., British Medical fournal $1970,2,139$.

${ }^{9}$ Gaddie, J., et al., British fournal of Diseases of the Chest, 1972, 66, 141.

10 Collier, J. G., et al., British fournal of Pharmacology, 1972, 44, 286.
11 Farmer, J. B., et al., British fournal of Pharmacology, 1972, 45, 660.

12 Palmer, K. N. V., and Diament, M. L., Lancet, 1969, 1, 591.

13 Richards, D. A., personal communication, 1973.

4 Kumana, C. R., Marlin, G. E., and Smith, D. M., in Proceedings of British Pharmacological Society. In press.

15 Richards, D. A., et al., British fournal of Clinical Pharmacology. In Press.

16 Boakes, A. J., Knight, E. J., and Prichard, B. N. C., Clinical Science, 1971, 40, $18 \mathrm{P}$.

17 Kennedy, I., and Levy, G. P., in Proceedings of Australian Physiological and Pharmacological Society. In press.

18 Taylor, S. H., British Medical fournal, 1974, 19, 49.

\title{
Fibrinolytic Capacity of Arm and Leg Veins after Femoral Shaft Fracture and Acute Myocardial Infarction
}

\author{
J. M. RAWLES, CHARLES WARLOW，D. OGSTON
}

British Medical fournal, 1975, 2, 61-62

\section{Summary}

The local fibrinolytic activity generated in the leg and arm veins during venous occlusion (fibrinolytic capacity) and the systemic fibrinolytic activity were measured at intervals in 11 patients after fracture of the femoral shaft and in 11 patients after acute myocardial infarction. In both groups the fibrinolytic capacity of the leg .veins and the systemic fibrinolytic activity were significantly reduced two days after the onset of tissue injury. The fibrinolytic capacity of the arm veins was not altered. These results provide a possible explanation for the predilection of venous thrombosis for the leg veins after accidental trauma and acute myocardial infarction.

\section{Introduction}

Deep venous thrombosis of the legs is a common complication of many forms of acute tissue injury-for example, surgery, ${ }^{1}$ accidental trauma, ${ }^{2}$ acute myocardial infarction, ${ }^{3}$ and strokes. ${ }^{4}$ Under these circumstances changes in platelet number and function, coagulation, and fibrinolysis occur which might favour thrombosis. ${ }^{5}$ Venous thrombosis more often affects the leg veins than the arm veins, ${ }^{6}$ however, which suggests that there is some difference in predisposition to thrombosis between the upper and lower limbs. The leg vein wall has a lower plasminogen activator content than the arm vein wall, ${ }^{7}$ and the release of plasminogen activator in response to venous occlusion"fibrinolytic capacity" - is also considerably less in the legs than in the arms. ${ }^{7}$ We studied the sequential changes in the fibrinolytic capacity of the arm and leg veins and the systemic fibrinolytic activity in patients who had fractured their femoral shaft or suffered acute myocardial infarction.

\section{Patients and Methods}

Ten men and one woman (age 18-71 years) were studied after fracture of one femoral shaft without other significant injury. They were treated by traction for at least two months. Blood samples were obtained two and 10 days after injury and again two months later. Seven patients were also studied two or more months after mobilization,

Department of Medicine, Aberdeen University, Aberdeen AB9 2ZD J. M. RAWLES, M.B., M.R.C.P., Senior Registrar (Present address: West Cornwall Hospital, Penzance)

CHARLES WARLOW, M.B., M.R.C.P., Lecturer (Present address: National Hospital for Nervous Diseases, Queen Square, London)

D. OGSTON, M.D., F.R.C.P., Senior Lecturer when they were ambulant for most of the day. Another 11 men (age 41-63) were studied two and 10 days after the clinical onset of acute myocardial infarction confirmed by serial electrocardiograms and raised serum aspartate aminotransferase levels.

In all patients blood was first drawn from an antecubital vein without venous occlusion for measurement of the systemic fibrinolytic activity. Sphygmomanometer cuffs were then applied to the upper arm (cuff size $22 \times 12 \mathrm{~cm}$ ) and thigh (cuff size $50 \times 17 \mathrm{~cm}$ ). The uninjured leg was used in the patients with fractures. The cuffs were simultaneously inflated to mid-way between the systolic and diastolic arterial blood pressure as recorded in the arm for 12.5 minutes. Blood was then withdrawn from a vein on the dorsum of the foot and from an antecubital vein before release of the occluding cuffs. The fibrinolytic activity of these samples obtained after venous occlusion was taken as the "fibrinolytic capacity." The fibrinolytic activity of each blood sample was measured by the euglobulin clot lysis time method, ${ }^{\circ}$ using a clot lysis time recorder (Carmanan Instrumentation Ltd., Glasgow). The results were expressed by plotting the lysis times logarithmically against units of fibrinolytic activity, ${ }^{10} 10$ units being arbitrarily equated with a lysis time of 50 minutes. The paired $t$ test was used for statistical comparisons.

\section{Results}

In both groups of patients the fibrinolytic capacity of the leg veins and the systemic fibrinolytic activity were significantly reduced two days after the onset of tissue injury. There was a significant increase $(\mathbf{P}<0.01)$ in the mean fibrinolytic activity of systemic blood between the second and 10th day after tissue injury in both groups (see table). In the patients with fractured femurs there was no further significant change two months after injury, though in the seven patients studied after mobilization there was a small but significant rise $(P<0.05)$ in systemic fibrinolytic activity from the level at two months. There were no significant changes in the mean arm fibrinolytic capacity after fracture or myocarcial infarction. There was, however, a significant increase in the mean leg fibrinolytic capacity of the leg veins between two and 10 days after fracture of the femur $(P<0.001)$ and acute myocardial infarction $(P<0.01)$. There was no further significant change either two months after femoral fracture or after mobilization in the seven patients who were studied when ambulant.

There was high correlation between the individual values of systemic fibrinolytic activity and leg fibrinolytic capacity $(r=0.79 ; P<0.001)$, but the correlation between systemic activity and arm fibrinolytic capacity was less close $(r=0.31 ; P<0.05)$.

\section{Discussion}

Our findings support observations of the early depression of systemic fibrinolytic activity after accidental trauma ${ }^{11}$ and acute myocardial infarction. ${ }^{12}$ We also found a significant depression in the fibrinolytic capacity of the legs only two days after femoral shaft fracture or myocardial infarction which correlated with the changes in systemic fibrinolytic activity. If the generation of fibrinolytic activity in the venous system in response to venous 